\title{
Anxiolytic and sedative-like effects of flavonoids from Tilia americana var. mexicana: GABAergic and serotonergic participation
}

\author{
Eva Aguirre-Hernández, ${ }^{1}$ Ma. Eva González-Trujano, ${ }^{2}$ Teresa Terrazas, ${ }^{3}$ Josefina Herrera Santoyo, ${ }^{1}$ \\ Patricia Guevara-Fefer ${ }^{1}$
}

Artículo original

\section{ABSTRACT}

\section{Introduction}

The inflorescences of Tilia americana var. mexicana are used as an infusion in Mexican traditional medicine due to their tranquilizing effects; however, pharmacological and phytochemical studies of the leaves are lacking.

\section{Objective}

In this research, the anxiolytic and sedative-like efficacy of the Tilia americana var. mexicana leaves was compared to that obtained with its inflorescences and flavonoids therein identified, as well as the possible mechanism of action.

\section{Methods}

The sorted and dried inflorescences and leaves were macerated subsequently in hexane, ethyl acetate and methanol. The methanol extracts were qualitative- and quantitative-analyzed by HPLC, using commercial flavonoids standards selected on the basis of their previously reported presence in Tilia species. The pharmacological activity was evaluated in CD-1 mice in the tests: open-field, elevated plus-maze, hole-board, and the sodium pentobarbital-induced sleep potentiation test. In regard to the mechanism of action, participation of benzodiazepine and $5-\mathrm{HT}_{1 \mathrm{~A}}$ serotonin receptors was tested with the respective antagonists: flumazenil and WAY 100635

\section{Results}

The presence of quercetin, rutin and isoquercitrin was confirmed in the extracts of the inflorescences and leaves. The anxiolytic-like effects were the same between the two organs, which were inhibited in the presence of flumazenil and WAY 100635.

\section{Discussion and conclusion}

Our results provide evidence that the extracts of the leaves of $T$. americana var. mexicana are as efficacious as the inflorescences to produce anxiolytic and sedative-like effects, where flavonoids like quercetin, rutin and isoquercitrin are partially responsible for these activities by the involvement of $\mathrm{GABA} / \mathrm{BDZ}$ and $5 \mathrm{HT}_{1 \mathrm{~A}}$ serotonergic receptors.

Key words: Anxiety, isoquercitrin, quercetin, rutin, sedative, Tilia.

\section{RESUMEN}

\section{Introducción}

En la medicina tradicional mexicana, la infusión de inflorescencias de Tilia americana var. mexicana es utilizada por sus efectos tranquilizantes; sin embargo, los estudios farmacológicos y fitoquímicos de sus hojas son deficientes.

\section{Objetivo}

En esta investigación, la eficacia ansiolítico-sedante de las hojas de T. americana var. mexicana se comparó con la obtenida con las inflorescencias y los flavonoides previamente identificados; se analizó además el posible mecanismo de acción.

\section{Métodos}

Inflorescencias y hojas separadas y secas se maceraron sucesivamente en hexano, acetato de etilo y metanol. Los extractos metanólicos se analizaron cualitativa y cuantitativamente por HPLC usando estándares comerciales de flavonoides previamente reportados en especies de Tilia. La actividad farmacológica se evaluó en ratones CD-1 en las pruebas de campo abierto, cruz elevada, tablero con orificios y la prueba de potenciación de hipnosis inducida por pentobarbital sódico. Respecto al mecanismo de acción, la participación de los receptores de benzodiazepinas y $5-\mathrm{HT}_{1 \mathrm{~A}}$ de serotonina se examinó utilizando los antagonistas flumazenil y WAY 100635, respectivamente.

\section{Resultados}

La presencia de quercetina, rutina e isoquercitrina se confirmó en los extractos de inflorescencias y hojas, donde se confirmó el efecto como ansiolítico, el cual fue inhibido en la presencia de flumazenil y WAY 100635

\section{Discusión y conclusión}

Nuestros resultados dan evidencia de que las hojas de T. americana var. mexicana son tan eficaces como las inflorescencias para producir efectos ansiolítico-sedantes, donde los flavonoides quercetina, rutina e isoquercitrina son responsables parciales y se involucra la participación de los receptores $\mathrm{GABA} / \mathrm{BDZ}$ y $5 \mathrm{HT}_{1 \mathrm{~A}}$ de serotonina.

Palabras clave: Ansiedad, isoquercitrina, quercetina, rutina, sedante, Tilia.

Departamento de Ecología y Recursos Naturales. Facultad de Ciencias, Universidad Nacional Autónoma de México.

Laboratorio de Neurofarmacología de Productos Naturales. Dirección de Investigaciones en Neurociencias del Instituto Nacional de Psiquiatría Ramón de la Fuente Muñiz.

Instituto de Biología, Universidad Nacional Autónoma de México.

Correspondence: Ma. Eva González-Trujano. Laboratorio de Neurofarmacología de Productos Naturales. Dirección de Investigaciones en Neurociencias. Instituto Nacional de Psiquiatría Ramón de la Fuente Muñiz, Calz. México-Xochimilco 101, San Lorenzo Huipulco, 14370 México, DF. México. Phone: (+52 55) 4160 - 5084. Fax: (+52 55) 5655 - 9980. E-mail: evag@imp.edu.mx

Received first version: June 6, 2014. Second version: June 22, 2015. Accepted: August 3, 2015 


\section{INTRODUCTION}

Tilia americana var. mexicana is distributed in 14 states of Mexico, from the north of Chihuahua and Coahuila to the south of Guerrero and Oaxaca. Its populations are mostly confined to the cloud forest, which covers less than $1 \%$ of the Mexican territory. ${ }^{1}$ In Mexico, the flowers infusion is used as a treatment for enterocolitis, gastroenteritis, hepatic and nephritic colics, but it is mostly generally used due to its depressant activity. ${ }^{2-5}$ To use Tilia as a tranquilizer, infusions are typically prepared with water brought just to a boil and afterward poured over the crushed inflorescences, but not the leaves; the concoction is covered and brewed for five minutes. The infusions can also be prepared directly in the drinking cup by merely pouring hot water over the vegetal material or by dropping powdered inflorescences into the water heating pot. In previous studies, a significant dose-dependent anxiolytic-like activity was demonstrated for methanolic and aqueous extracts of Tilia inflorescences, further glycosides of quercetin and kaempferol were characterized and suggested as the main active compounds. ${ }^{6,7}$

It is known that the quality and quantity of secondary metabolites particularly tend to fluctuate depending on factors such as genetic drift, physiological conditions, season, and harvesting time, as well as sample preparation and analytical method..$^{8-10}$ Numerous investigations on the aforementioned factors have been conducted; as a result, it has been found that the phenological stage and collection site strongly influence the quantity of secondary metabolites. ${ }^{9,11}$ Moreover, it is acknowledged that flowers and leaves show considerable heterogeneity in their flavonoid contend when samples come from different sites., ${ }^{9,11}$ The flavonoid pattern differences between inflorescences and leaves and its potential contribution to the therapeutic properties of Tilia is unknown. Therefore, in this study we examined the flavonoid composition of methanolic extracts of either inflorescences or leaves of T. americana var. mexicana collected in three different regions of Mexico, and furthermore examined their anxiolytic and sedative-like activities as well as the mechanism of action. It has been reported that natural flavonoids possess a selective and relatively mild affinity for benzodiazepine receptors, ${ }^{12}$ but some of them might also produce their tranquilizing activity by acting on serotonergic receptors. ${ }^{13,14}$ In a preliminary study, the extract of $T$. americana var. mexicana inflorescences produced anxiolytic and sedative-like effects where, at the same $100 \mathrm{mg} / \mathrm{kg}$, i.p. dosage, the methanol had a higher response than the hexane and ethyl acetate extracts. ${ }^{7}$ The antinociceptive activity of this species in an arthritic pain model involving $5-\mathrm{HT}_{1 \mathrm{~A}}$ receptors was demonstrated in other study. ${ }^{15}$ Another study reports that the anxiolytic-like effects of a standardized fraction from inflorescences of T. americana is mediated by serotonergic receptors; the standardization was supported in the flavonoids contained: tiliroside, rutin, quercetin, a quer- cetin glucoside and kaempferol. ${ }^{14}$ Based on this evidence and given that the mechanism of action of the anxiolytic and sedative-like effects of Tilia extracts is poorly known, our hypothesis is that their leaves produce the same anxiolytic and sedative-like effects than the inflorescences because of the presence of these metabolites and it is mediated by the participation of benzodiazepines and $5-\mathrm{HT}_{1 \mathrm{~A}}$ receptors.

\section{MATERIALS AND METHODS}

\section{Plant material}

Inflorescences and leaves of Tilia americana L. var. mexicana (Schltdl.) Hardin (Malvaceae) ${ }^{16}$ were collected in June 2010 in three regions of Mexico, viz.: Morelia, Michoacan (FCME131611), Santa María Ahuacatitlan, Morelos (FCME131612) and Honey, Puebla (FCME131613). The species identification was provided by José Luis Contreras; voucher specimens were deposited at the Herbarium of the Faculty of Sciences of the National Autonomous University of Mexico (UNAM), Mexico City.

\section{Extracts preparation}

The inflorescences (flowers and bracts) and leaves were sorted for each plant, and then air-dried. Powdered inflorescences (15 g) and leaves (15 g) were successively extracted with hexane $(1 \mathrm{~L} \times 3)$, ethyl acetate $(1 \mathrm{~L} \times 3)$ and methanol $(1 \mathrm{~L} \times 3)$ by maceration at room temperature $\left(22^{\circ} \mathrm{C}\right)$. The solvents were separated from the residues by gravity filtration and then evaporated in vacuum. The dry weight percentage (\% d.w.) obtained for the methanol extracts from the three regions mentioned were as follows: inflorescences $(1.52 \mathrm{~g}$, $10.13 \% ; 1.81 \mathrm{~g}, 12.06 \%$; and $1.73 \mathrm{~g}, 11.53 \%)$, and leaves $(1.14 \mathrm{~g}$, $7.60 \% ; 0.56 \mathrm{~g}, 3.73 \%$ and $1.41 \mathrm{~g}, 9.40 \%$, respectively).

\section{High performance liquid chromatography (HPLC) analysis}

For each extract, a methanolic stock solution $(1 \mathrm{mg} / \mathrm{mL})$ was prepared and passed through a $0.45 \mu \mathrm{m}$ pore size filter. A $20 \mu \mathrm{L}$ aliquot was injected into a HPLC system (Agilent Technologies) equipped with a ODS hypersil C-18 column (125 mm x 4 mm i.d., $5 \mu \mathrm{m}$ particle size). The mobile phase consisted in solvent $\mathrm{A}$, water ( $\mathrm{pH} 2.5$, trifluoroacetic acid) and solvent B acetonitrile, in gradient elution as follows: 85:15 (min 0-4), 65:35 ( $\min 5-12$ ), 65:35 (min 13-14). The column temperature was constant at $30^{\circ} \mathrm{C}$ and the flow was 1 $\mathrm{mL} / \mathrm{min}$. Total running time was $14 \mathrm{~min}$. Calibration curves were made for each commercial standard of the flavonoids: kaempferol, quercetin, rutin, astragalin, isoquercitrin and quercitrin. Chromatograms detection was set at $350 \mathrm{~nm}$. The selection of the flavonoids present in Tilia species was based 
on the literature reports of T. americana var. Mexicana, ${ }^{7,14,17} \mathrm{~T}$. Platyphyllos, T. rubra and T. Argentea, ${ }^{9}$ as well as T. Tomentosa. ${ }^{18}$

\section{Animals}

Male CD-1 mice (25-30 g body weight) were obtained from the animal housing facility of the Faculty of Medicine, UNAM, and kept under standardized conditions. All experimental procedures were carried out according to a protocol approved by the local Animal Ethics Committee (NC093280.2) in compliance with national (NOM-062ZOO-1999) and international regulations on the care and use of laboratory animals.

\section{Drugs}

Commercial flavonoids such as kaempferol, quercetin, rutin, astragalin, isoquercitrin and quercitrin standards, as well as flumazenil and WAY100635, were purchased from Sigma (Sigma-Aldrich Co., St Louis, MO, USA). Sodium pentobarbital was obtained from Sedalphorte ${ }^{\mathrm{TM}}$ from Salud y Bienestar Animal Laboratory (Mexico, DF). Extracts were prepared on the day of the experiments, resuspended in saline solution (s.s. $0.9 \%, \mathrm{NaCl}$ ) and administered intraperitoneally (i.p.) in a volume of $10 \mathrm{~mL} / \mathrm{kg}$ body weight. Control animals received only vehicle in the same volume and administration route.

\section{Pharmacological evaluation}

Each treatment was considered as an independent group of six mice $(n=6)$. Experimental groups that received a dosage of methanol extract (100 mg/ $\mathrm{kg}$ body weight, i.p.) from flowers or leaves were evaluated and compared with the control animals administered with only s.s. After $60 \mathrm{~min}$, each mouse received sodium pentobarbital (42 mg/ kg, i.p.) to induce hypnosis. Other independent groups $(n=6)$ that received an individual commercial flavonoid (kaempferol, astragalin, quercetin, isoquercetin, quercitrin and rutin) or the mixture made with the tree commercial flavonoids: quercetin $(20 \mathrm{mg} / \mathrm{kg})$, isoquercitrin $(2 \mathrm{mg} / \mathrm{kg})$, and rutin $(15.70 \mathrm{mg} / \mathrm{kg}$ ) were evaluated for anxiolytic and/or sedative-like responses $50 \mathrm{~min}$ after administration of the flavonoids. Finally, for the evaluation of the mechanism of action, independent groups of mice were treated with the antagonists flumazenil (5 mg/kg, i.p.) or WAY100635 (0.32 mg/kg, i.p.) fifteen min before the administration of the methanol extract $(100 \mathrm{mg} / \mathrm{kg}$ ) or the flavonoid mixture. After $50 \mathrm{~min}$ of the last administration, animals were successively evaluated in the following tests.

\section{Ambulatory activity}

Fifty minutes after the methanol extracts administration and prior to the anti-anxiety and sedative assay, each mouse was placed individually into a cage divided in 12 squares $(6 \mathrm{~cm} \times 6 \mathrm{~cm})$. Ambulatory activity was registered as the number of squares explored by each mouse in a 2 min lapse. ${ }^{6}$

\section{Anti-anxiety and sedative-like activities}

After ambulatory activity, the anti-anxiety and sedative-like responses to the methanol extracts were successively evaluated with the following tests; it is important to mention here that the inner side of each apparatus and floor were cleaned with an alcoholic solution between each animal test session:

The elevated plus-maze: A modified test was used. ${ }^{19}$ The maze consists of two open arms $(25 \mathrm{~cm} \times 5 \mathrm{~cm})$, facing each other, and two closed arms $(25 \mathrm{~cm} \times 5 \mathrm{~cm} \times 15 \mathrm{~cm})$ with open roof and walls of $40 \mathrm{~cm}$ height. A mouse was placed in the center and then an observer measured the total time spent in open-sided arms during a 5 min lapse.

Hole-board test: A mouse was placed in the center of a perforated board; the number of head-dips was registered for 3 minutes. The test board was made by boring 16 evenly spaced holes ( $3 \mathrm{~cm}$ in diameter) on a plastic floorboard, delimited by a glass box $20 \mathrm{~cm}$ height and $20 \mathrm{~cm}$ deep. ${ }^{20}$

Sodium pentobarbital-induced hypnosis: $60 \mathrm{~min}$ after the corresponding methanol extract ( $100 \mathrm{mg} / \mathrm{kg}$ i.p.) each mouse received sodium pentobarbital (42 $\mathrm{mg} / \mathrm{kg}$, i.p.) to induce hypnosis. Mice were immediately placed individually in a translucid acrylic box to be observed for the onset of uncoordinated movements (sedative phase) and hypnosis, and for sleep duration. The criterion for sleep or hypnosis is defined as the loss righting reflex. The time between loss and recovery of the righting reflex was recorded as sleeping time. ${ }^{21}$

\section{Statistical analysis}

Results are expressed as the mean \pm SEM. Statistical differences were evaluated by analysis of variance (ANOVA), either a one-way ANOVA followed by Tukey's test to explore differences among means or two-way ANOVA followed by Tukey's test to analyze data of flavonoids concentrations depending on the part of the plant and the collected region. A value of $\mathrm{P}<0.05$ was considered significant. The GraphPad Prism ${ }^{\circledR}$ version 4.00 software program was used.

\section{RESULTS}

The ambulatory activity of mice treated with methanol extract from inflorescences or leaves of Tilia was not statistically different to the controls, with the exception of the inflorescences extract from Michoacan which significantly reduced $(40 \%)$ the squares explored in the open field test when compared with animals treated with vehicle or other extract (figure 1A). With regard to the anxiolytic-like effects, all samples were associated with a significant diminution in head dips during the exploratory behavior in the hole- 
board (figure 1B), alongside an increase in time spent at the open-sided arms in the plus-maze; the effects were more pronounced with samples from leaves of Michoacan and
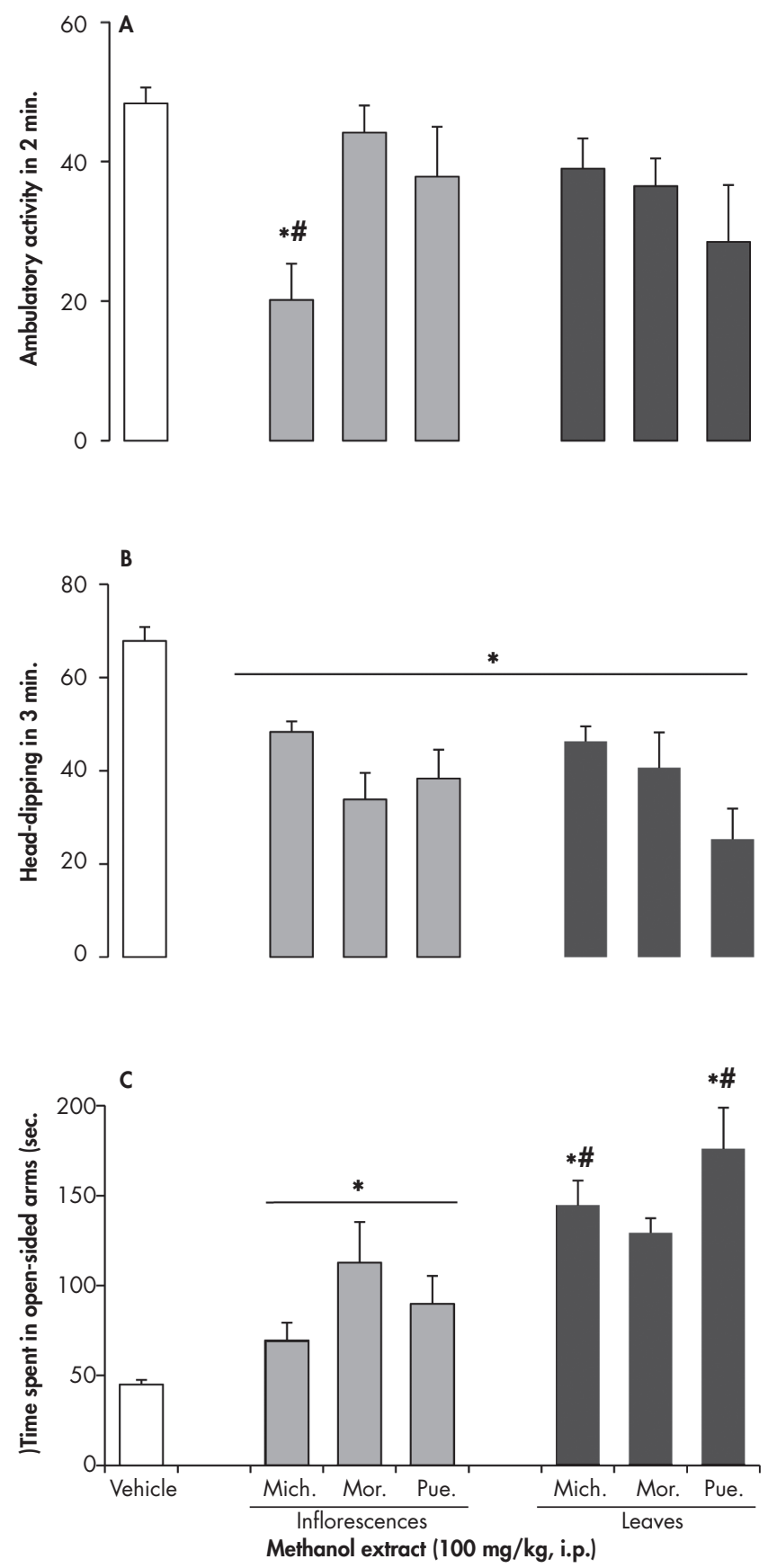

Figure 1. Anxiolytic and sedative-like responses of mice to the methanol extracts $(100 \mathrm{mg} / \mathrm{kg}$ i.p.) of inflorescences and leaves from T. americana var. mexicana collected in Michoacan $(\mathrm{MICH})$, Morelos (MOR) and Puebla (PUE), Mexico; evaluated with the open-field (A), hole-board (B) and plus-maze (C) tests. Each bar represents the mean \pm S.E.M. of at least six animals. Two way ANOVA followed by Tukey's test.

${ }^{*} P<0.05$ vs. region

$\because P<0.05$ inflorescences vs. leaves
Puebla (figure 1C). All treatments produced a similar significant potentiation in the sodium pentobarbital-induced hypnosis test in comparison to the vehicle group (table 1); only the Michoacan sample obtained from Tilia leaves produced a significant facilitation of sedation (table 1).

Differences in flavonoid concentrations of leaves or inflorescences were found among regions (figure 2). The flavonoid pattern of all the active samples showed in common the presence of quercetin and rutin (figure 3). In the present work, high concentrations of quercetin were observed in inflorescences, particularly from Puebla; the lowest concentrations were detected in samples from Morelos (figures 2 and 3). In contrast, rutin was observed mainly in leaves from Michoacan, followed by samples from Morelos and, in a lesser degree, in the samples from Puebla (figures 2 and 3). Isoquercitrin had similar concentrations in the leaf samples from the three regions, but it was only detected and quantified in the inflorescences from Puebla, and detected, but not in a quantifiably amount, in Morelos and Michoacan (figures 2 and 3). Quercitrin, astragalin and kaempferol were not detected in any sample of this study (figure 3).

Concerning the pharmacological activity of the identified flavonoids, only isoquercitrin, alone or mixed with rutin and quercetin, produced a sedative-like response with significant a diminution of the ambulatory activity of the mice (figure 4A). A significant decrease in head-dipping behavior was observed with all the flavonoids tested in the hole-board test (figure 4B). This anxiolytic-like response was reinforced with an increase in the time spent in openside arms in the plus-maze model (figure 4C); however, this response was no detected for astragalin and quercitrin with this model (figure 4C). Individual administration of isoquercitrin and rutin showed a major effect in comparison with the mixture (figure 4C).

With regard to the mechanism of action, the admin-

Table 1. Effect of methanol extracts $(100 \mathrm{mg} / \mathrm{kg}$, i.p.) obtained from the Tilia americana var. mexicana inflorescences and leaves on the sodium pentobarbital-induced hypnosis potentiation in mice

\begin{tabular}{|c|c|c|c|}
\hline \multirow{2}{*}{$\begin{array}{l}\text { Location } \\
\text { treatment }\end{array}$} & \multicolumn{2}{|c|}{ Latency to the onset ( $\mathrm{min}$ ) } & \multirow{2}{*}{$\begin{array}{c}\text { Duration of } \\
\text { the hypnosis }(\mathrm{min})\end{array}$} \\
\hline & Sedation & Hypnosis & \\
\hline Vehicle & $1.19 \pm 0.04$ & $2.56 \pm 0.15$ & $20.18 \pm 1.33$ \\
\hline \multicolumn{4}{|l|}{ Michoacan } \\
\hline Inflorescences & $1.09 \pm 0.10$ & $2.37 \pm 0.14$ & $49.74 \pm 2.74$ * \\
\hline Leaves & $0.83 \pm 0.04$ * & $2.27 \pm 0.22$ & $55.33 \pm 10.33$ * \\
\hline \multicolumn{4}{|l|}{ Morelos } \\
\hline Inflorescences & 1.20 & 2.49 & $54.48 \pm 11.71$ * \\
\hline Leaves & $1.06 \pm 0.04$ & $2.33 \pm 0.13$ & $57.24 \pm 12.99$ \\
\hline \multicolumn{4}{|l|}{ Puebla } \\
\hline Inflorescences & $0.92 \pm 0.06$ & $2.09 \pm 0.13$ & $69.71 \pm 9.65^{*}$ \\
\hline Leaves & $1.15 \pm 0.09$ & $2.56 \pm 0.06$ & $45.60 \pm 1.31$ * \\
\hline
\end{tabular}

Data are represented as the mean \pm S.E.M. of at least six animals. ${ }^{*} P<0.05$, one way ANOVA followed by Tukey's test. Differences were observed only when compared with the vehicle group. 

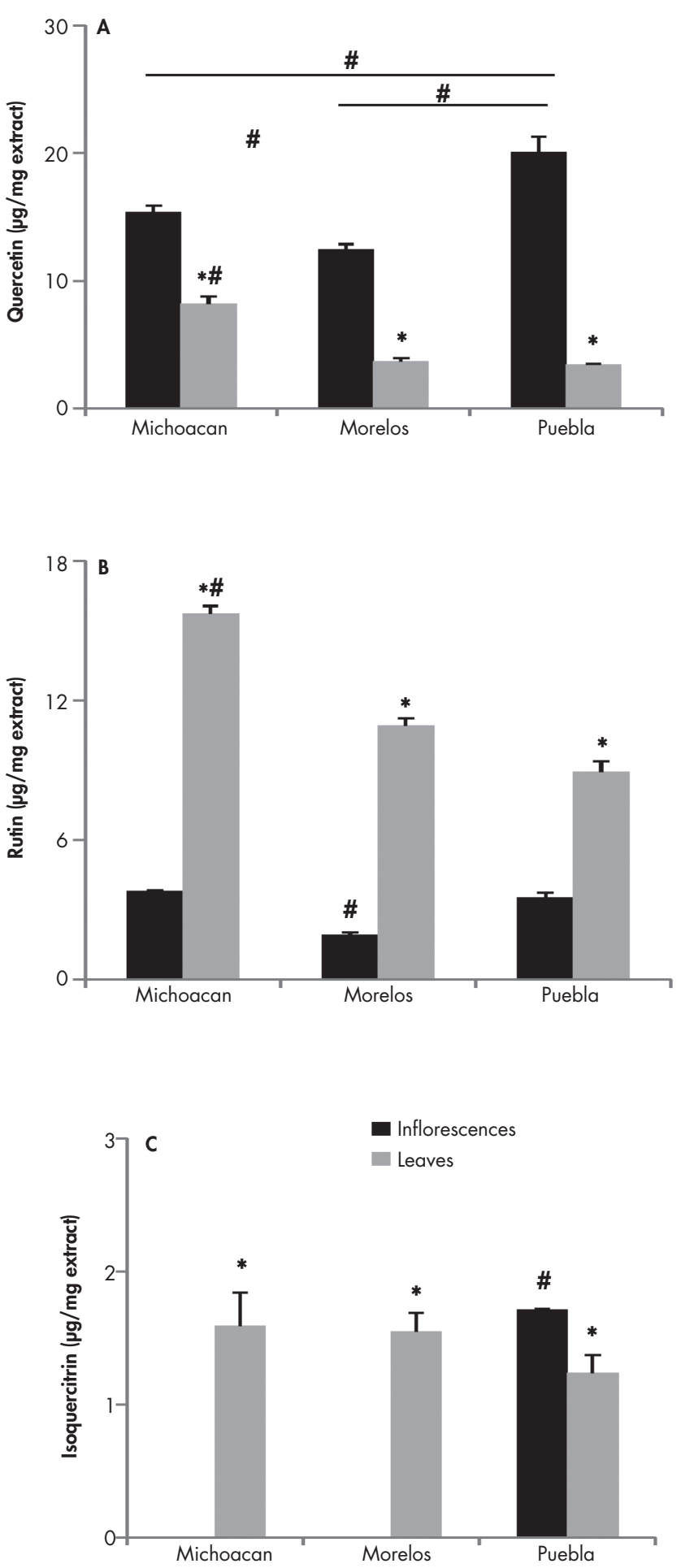

Figure 2. HPLC analysis of flavonoids concentrations $(\mu \mathrm{g} / \mathrm{mg}$ of extract) in the methanol extracts from inflorescences and leaves of the Tilia americana var. mexicana samples from different region, such as: quercetin $(F 2,12=35.28, P<0.001)(A)$; rutin $(F 2,12=70.32$, $P<0.001)(B)$, and isoquercetrin $(F 2,12=42.98, P<0.001)(C)$. Data are expressed as the mean \pm S.E.M. of three samples. Two way ANOVA followed by Tukey's test.

${ }^{*} P<0.01$ leaves vs. inflorescences $\# P<0.001$ among collected region istration of BDZs and 5- $\mathrm{HT}_{1 \mathrm{~A}}$ antagonists (flumazenil and WAY100635, respectively) in mice that received extract did not modify the ambulatory activity, whereas the flavonoid mixture in the presence of WAY100635 showed a significant decrease in the number of explorations (figure $5 \mathrm{~A}$ ). In the hole-board test, neither antagonist modified the response of the extract or flavonoid mixture (figure 5B). On the contrary, both antagonists inhibited the anxiolytic-like effects of the flavonoid mixture in the plus-maze test (figure 5C).

\section{DISCUSSION AND CONCLUSION}

In this study, differences in the anxiolytic and sedative-like activities and flavonoid profile of inflorescences and leaves of T. americana var. mexicana were investigated in samples from three different regions of Mexico. This flavonoid pattern exhibited significant differences that depended on the plant part and the collection site. Regardless of these differences, anxiolytic and sedative-like responses were observed in all the samples. The partial involvement of BDZs and 5- $\mathrm{HT}_{1 \mathrm{~A}}$ receptors was suggested as a possible mechanism of action participating in the effect of the methanol extract of T. americana var. mexicana and the mixture of flavonoids obtained from it.

Traditional medicine information mentions the exclusive utilization of the inflorescences (flowers and bracts) of Tilia species due to their tranquilizing properties. Previous studies reported that inflorescences of T. americana var. mexicana collected in different regions of Mexico such as Michoacan, ${ }^{6}$ Estado de Mexico, ${ }^{17}$ Guerrero, Hidalgo and Veracruz ${ }^{7}$ produce anxiolytic and sedative-like effects on mice. These investigations agree with others from Latin American (T. tomentosa) and European (T. platyphyllos, T. rubra and T. argentea) species of Tilia ${ }^{9,18,22}$ corroborating such therapeutic property of flowers and bracts. Even though Tilia has as a genus a relatively large geographical distribution, the populations of T. americana var. mexicana covers less than $1 \%$ of the Mexican territory. ${ }^{1}$ It has been observed that during the flowering months (April-June), the marketing of inflorescences increases, due to the popular belief that the medicinal effect of the infusion is greater during this period..$^{23}$ Tilia species are trees up to $20 \mathrm{~m}$ high and $1 \mathrm{~m}$ in diameter. This causes a disadvantage in its exploitation as a medicinal resource since the utilization of inflorescences reduces the production of seeds and the establishment of new Tilia individuals in their populations. ${ }^{23}$ Additionally, we made a preliminary analysis of the seeds using the tetrazolium test (data not shown) which showed low viability. Our results are in agreement in that inflorescences of T. americana var. mexicana collected from three different regions of Mexico produce anxiolytic and sedative-like effect equivalent to those of Tilia species previously reported and thus underline the medicinal properties accredited to the genus.,14,17,18 Moreover, no difference in the tranquilizing activity was found between Tilia leaves 

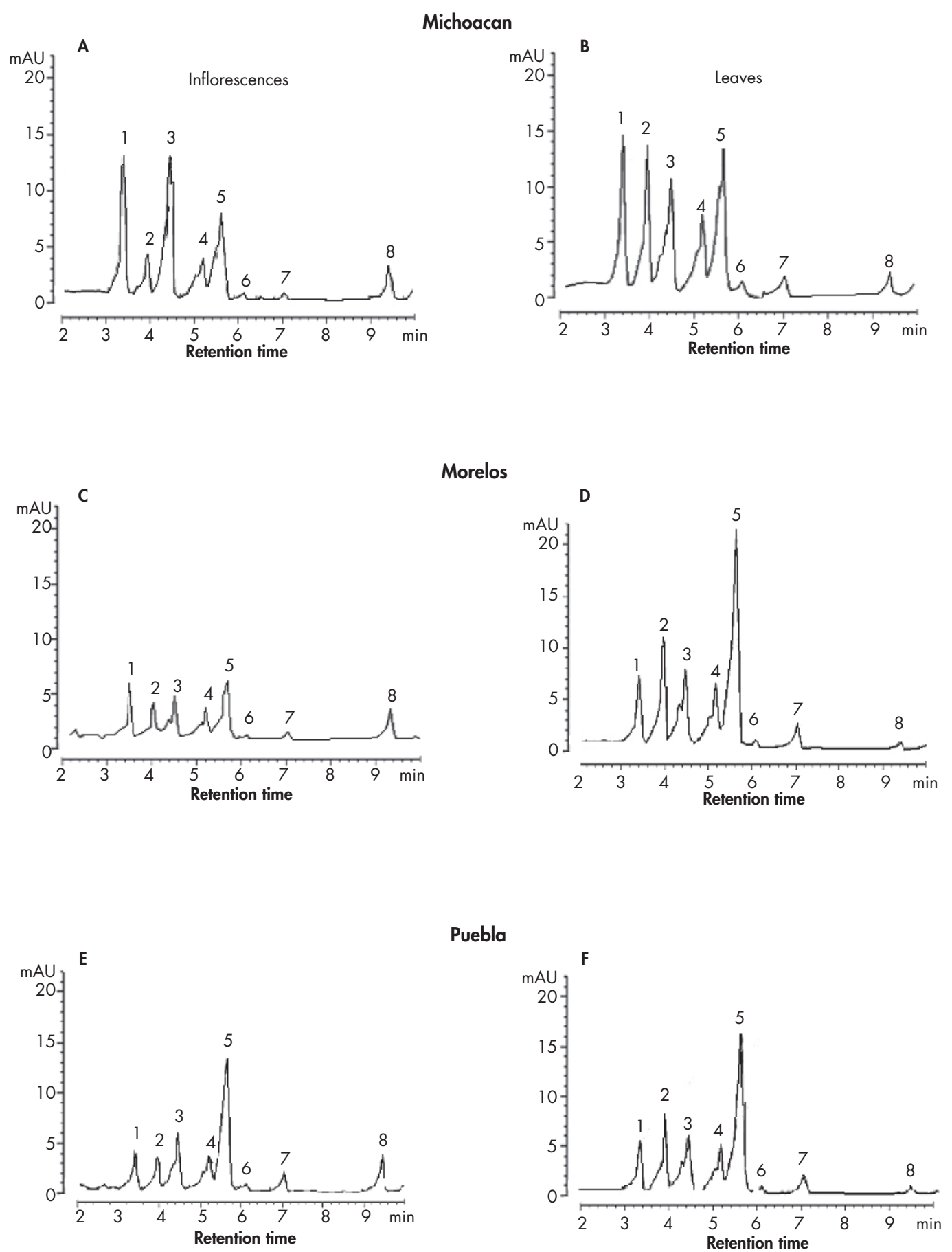

Figure 3. HPLC chromatogram of the flavonoid profile of methanol extracts from T. americana var. mexicana comparing inflorescences versus leaves in samples from Michoacan (A-B), Morelos (C-D) and Puebla (E-F), Mexico. The peaks identified were rutin (2); isoquercitrin (7) and quercetin (8).

and inflorescences. These findings reinforce the medicinal properties mentioned for Tilia and provide evidence that leaves can also be used for therapeutic purposes. It is important to notice that in contrast to the inflorescences, leaves can be collected in larger amounts so the endangerment of this species could be reduced by allowing an increase in the local population. In addition, the price of the product sold in markets may be also reduced and its availability extended all year round.

The selection of the studied flavonoids was based on previous research of Mexican (T. americana var. mexicana) and European (T. platyphyllos, T. rubra and T. argentea) spe- 

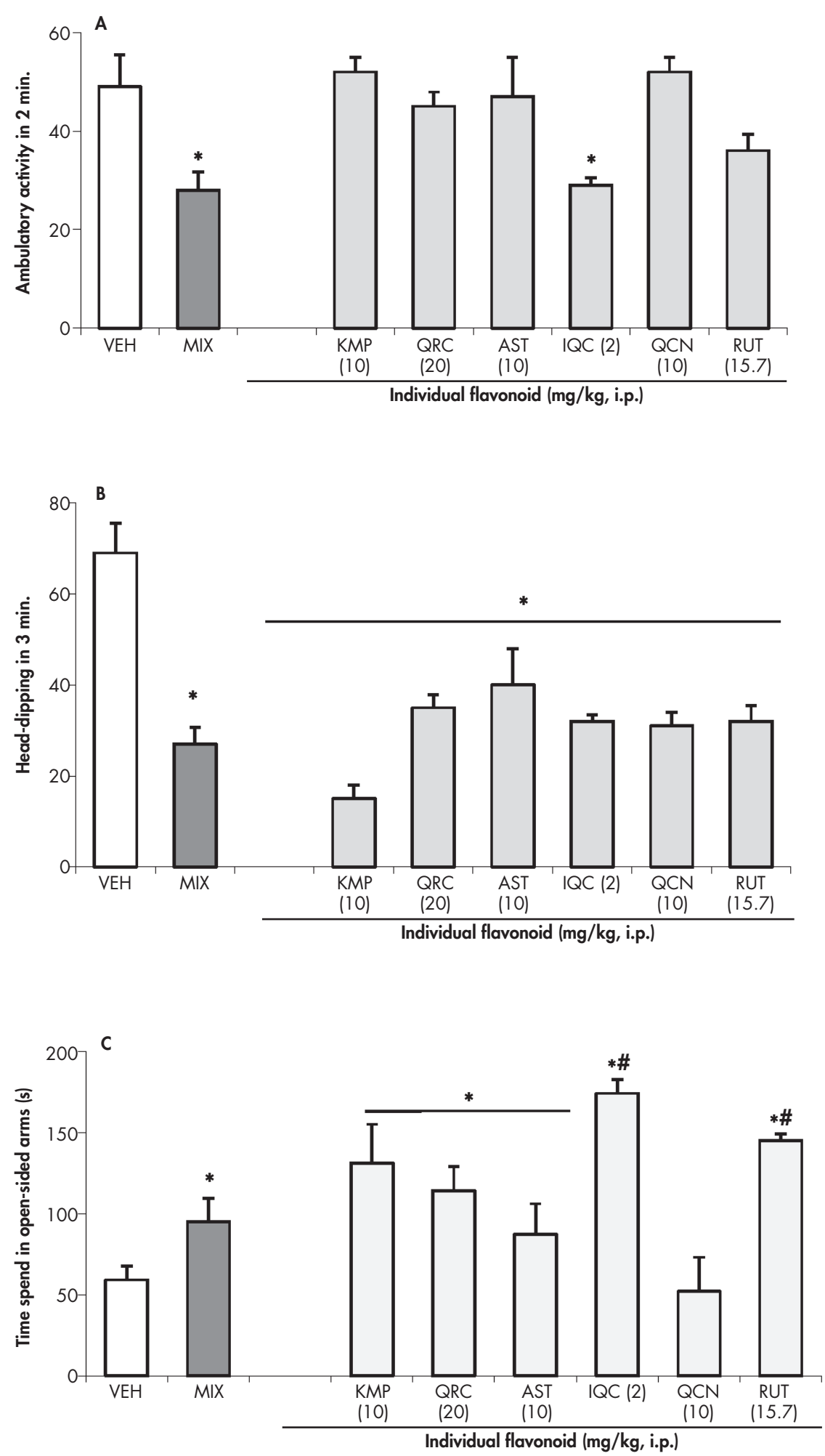

Figure 4. Anxiolytic and sedative-like responses to a mixture of flavonoids (MIX) composed of quercetin $20 \mathrm{mg} / \mathrm{kg}(Q R C)$, rutin $15.7 \mathrm{mg} / \mathrm{kg}$ (RUT) and isoquercitrin $2 \mathrm{mg} / \mathrm{kg}$ (IQC) compared to the individual response of commercial flavonoid standards (previously identified in other Tilia species): kaempferol (KMP), astragalin (AST) and quercitrin (QCN). Behavioral tests: open field (A), hole-board (B) and plus-maze (C). One way ANOVA followed by Tukey's test. ${ }^{*} P<0.001$ vs vehicle, ${ }^{P} P<0.05$ vs MIX.

Aguirre-Hernández et al., 2015 

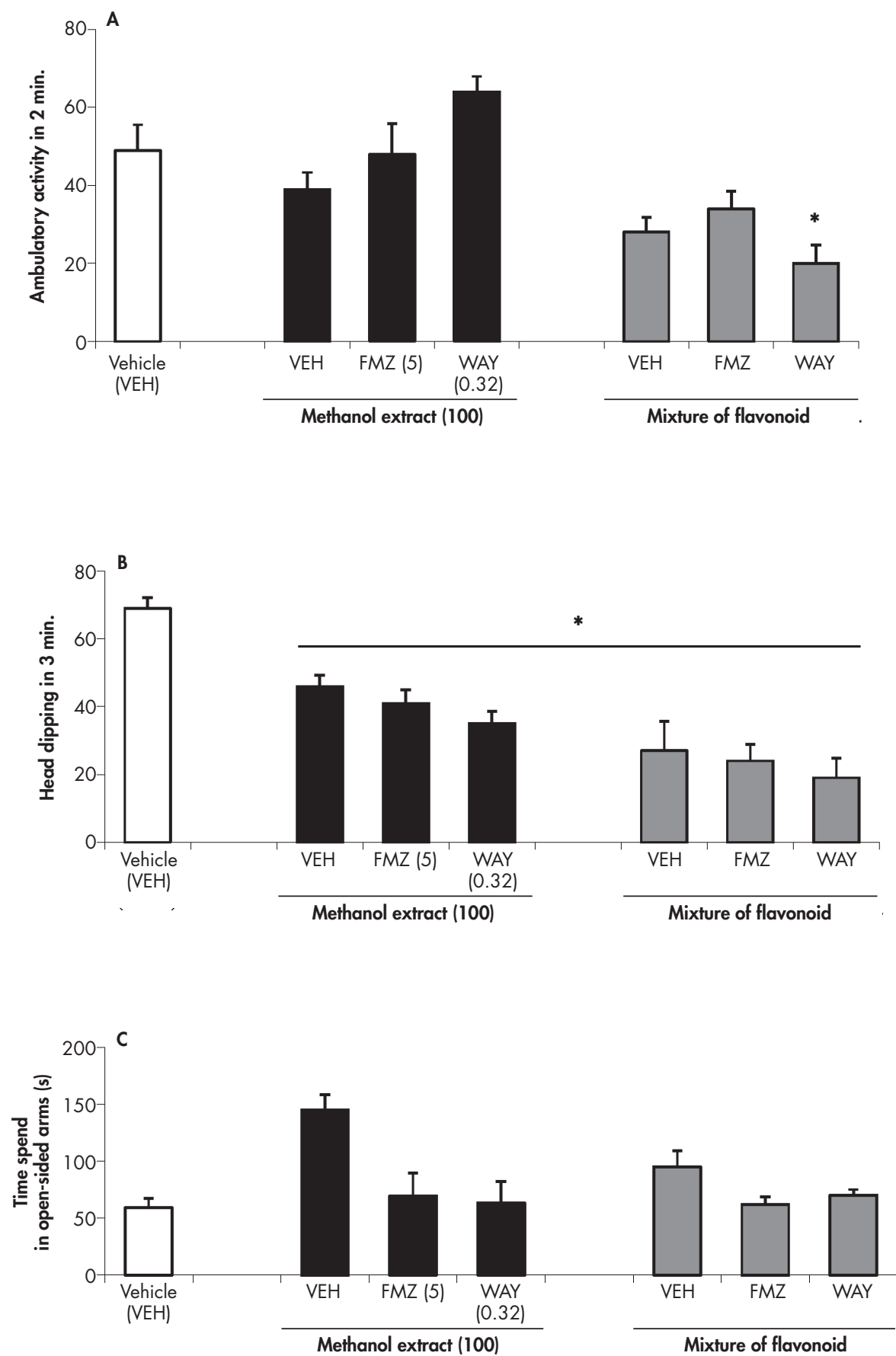

Figure 5. Anxiolytic and sedative-like responses to the methanol crude extract and a mixture of flavonoids composed of quercetin $(20 \mathrm{mg} / \mathrm{kg})$, rutin $(15.7 \mathrm{mg} / \mathrm{kg})$ and isoquercitrin $(2 \mathrm{mg} / \mathrm{kg})$ evaluated in the presence of flumazenil or WAY100635, antagonists of the GABAA/BDZs and 5-HTIA receptors respectively, using the open field (A), hole-board (B) and plus-maze (C) behavior tests. Each bar represents the mean \pm S.E.M. of at least six animals.

${ }^{*} P<0.001$, one way ANOVA followed by Tukey's test.

cies of Tilia. ${ }^{7,9,17}$ In a preliminary study, quercetin was not detected in samples from Guerrero, Hidalgo and Veracruz, and rutin was absent in samples from Hidalgo. ${ }^{7}$ Quercitrin, astragalin and kaempferol, previously reported in samples from other regions of Mexico, 7,17 were not detected in any of the studied samples. Our results are in agreement in that the presence of flavonoids differs depending also on the part of the plant and on the region of collection. Quercetin and 
rutin had the higher concentrations observed. It has been described that quercetin, a flavonol, is abundant in flowers. The primary function of flavonoids in flowers is to attract insects and other animals thus helping cross pollination. ${ }^{24}$ They additionally provide protection against UV irradiation and act as chemical defenses against pathogens; these roles are similar in other plant parts such as leaves. ${ }^{25}$ Furthermore, flavonoids are important for pollen germination, ${ }^{24}$ therefore their presence is crucial for the primary function of flowers that is plant reproduction. With respect to their therapeutic importance as anxiolytic and sedative-like compounds, it has been demonstrated that flavonoids such as quercetin, rutin and kaempferol elicit Central Nervous System activity involving the inhibitory GABAergic system. ${ }^{18,26,27}$ As described, rutin was the other abundant flavonoid detected in the active extract; it is known that plants increase glycosylated aglicone production as a mechanism to avoid damage. ${ }^{28}$ This property of plants is also an advantage in folk medicine, since they can be used as tranquilizers, among other therapeutic properties. On the other hand, the low amount of isoquercitrin and absence of kaempferol, astragalin, and quercitrin in the samples from three regions of Mexico suggest the existence of chemotypes between Tilia species and indicate the environmental characteristics as a primordial factor for the production of these metabolites as has been previously reported for samples from other regions. ${ }^{7}$

The precise mechanisms of action of flavonoids might differ depending on the chemical structure and pharmacological activity, but regarding the anti-anxiety and sedative-like activities, the involvement of the GABAergic and serotonergic systems is typically reported. . $2,14,29,30$ Nevertheless, many flavonoids have been described to produce depressant activity on the Central Nervous System mediated by other than $\mathrm{GABA}_{\mathrm{A}} /$ benzodiazepine or $\mathrm{GABA} /$ non benzodiazepinic receptors. ${ }^{14,31,32}$ In the present study, a crude methanol extract and a flavonoid mixture of T. americana var. mexicana leaves produced an anxiolytic-like effect that was reverted in presence of the benzodiazepine and $5-\mathrm{HT}_{1 \mathrm{~A}}$ receptor antagonists, flumazenil (5 mg/kg, i.p.) and WAY100635 (0.32 mg/ $\mathrm{kg}$, i.p.), respectively. The flavonoid mixture, composed of quercetin, isoquercitrin and rutin, was identified as partially responsible for the found activity, suggesting a synergy between these and other likely constituents in relation to their anxiolytic and sedative-like activities, which are mediated by GABAergic and serotonergic systems. Our results are in agreement to that reported in the literature, where the anxiolytic effect of a flavonoid standarized fraction obtained from a methanol extract of $T$. americana was antagonized in the presence of WAY-100635, ${ }^{14}$ both studies give evidence that serotonergic system participates in the anxiolytic and sedative-like effects of this medicinal species.

In conclusion, our results demonstrate that the anxiolytic and sedative-like effects of leaves of T. americana var. mexicana leaves are as efficacious as those observed with the inflorescences due to the presence of flavonoids like quercetin, rutin and isoquercitrin, suggesting the involvement of GABAergic and serotonergic receptors. The tranquilizing activity of T. americana var. mexicana is unaltered by the differences in the profile and amount of the flavonoids contained in the extract, suggesting that these compounds may be useful for the extract standardization. Furthermore, the effects are also produced by leaf extracts; this offers a possibility for resource management, since promoting the use of leaves, instead of inflorescences for the infusion preparation, would maintain the therapeutic benefits, without affecting the proliferation of trees of this species.

\section{Funding}

This work was supported by grants CONACYT-80811, CONACYT-226454 and INP-NC093280.2.

\section{Conflict of interests}

The authors declare that there are no conflicts of interest.

\section{Acknowledgements}

The authors are grateful to Dr. Enrique Pinzón Estrada, Dr. Ismael Torres Saldaña, MSc Rubén San Miguel Chávez, Mr. Raúl Cardoso, Mr. José Luis Calderon and M Sc R Enrique Llanos-Romero for their technical assistance. We also thank Aidé M. González the proofreading of the English version of this manuscript.

\section{REFERENCES}

1. González-Espinosa M, Meave JS, Lorea-Hernández FG, Ibarra-Manríquez $\mathrm{G}$ et al. The red list of Mexican cloud forest trees. Cambridge, UK: Fauna and Flora International; 2011.

2. Martínez M. Medicinal plants of Mexico. Mexico: Botas; 1969.

3. Estrada EL. Botanical garden of medicinal plants "Maximino Martínez" (1888-1964). Chapingo, State of Mexico: Autonomous University of Chapingo; 1985.

4. Aguilar A, Camacho JR, Chino S, Jácquez $P$ et al. Herbal medicinal of the Mexican Institute of Social Security. Etnobotanic information. Mexico: Mexican Institute of Social Security; 1994.

5. Argueta A, Cano L, Rodarte M. Atlas of the plants of Mexican traditional medicine. Mexico: National Indigene Institute; 1994.

6. Pérez-Ortega G, Guevara-Fefer P, Chávez M, Herrera J et al. Sedative and anxiolytic efficacy of Tilia americana var. mexicana inflorescences used traditionally by communities of State of Michoacan, Mexico. J Ethnopharmacol 2008;116:461-468.

7. Aguirre-Hernández E, González-Trujano ME, Martínez AL, Moreno $\mathrm{J}$ et al. HPLC/MS analysis and anxiolytic-like effect of quercetin and kaempferol flavonoids from Tilia americana var. mexicana. J Ethnopharmacol 2010;127:91-97.

8. Pietta P, Mauri P, Bruno A, Zini L. High-performance liquid chromatography and micellar electrokinetic chromatography of flavonol glycosides from Tilia. J Chromatogr A 1993;638:357-361.

9. Toker G, Aslan M, Yesilada E, Memisoglu M et al. Comparative evaluation of the flavonoid content in oficinal Tiliae flos and Turkish lime species for quality assessment. J Pharm Biomed Anal 2001;26:111-121.

10. De Rijke, E, Out P, Niessen WMA, Ariese F et al. Analytical separation and detection methods for flavonoids. J Chromatogr A 2006;1112:31-63.

11. Hosni K, Msaada K, Taarit MB, Marzouk B. Phenological variations 
of secondary metabolites from Hypericum triquetrifolium Turra. Biochem Syst Ecol 2011;39:43-50.

12. Medina JH, Viola H, Wolfman C, Marder M et al. Overview-flavonoids: a new family of benzodiazepine receptor ligands. Neurochem Res 1997;22:419-425.

13. Wang LE, Zhang XQ, Yin YQ, Zhang YH. Augmentative effect of spinosin on pentobarbital-induced loss of righting reflex in mice associated with presynaptic 5- $\mathrm{HT}_{1 \mathrm{~A}}$ receptor. J Pharm Pharmacol 2012;64:277-282.

14. Noguerón-Merino MC, Jiménez-Ferrer E, Román-Ramos R, Zamilpa $A$ et al. Interactions of a standardized flavonoid fraction from Tilia americana with serotoninergic drugs in elevated pluz maze. J Ethnopharmacol 2015;164:319-327.

15. Martínez AL, González-Trujano ME, Aguirre-Hernández E, Moreno J et al. Antinociceptive activity of Tilia americana var. mexicana inflorescences and quercetin in the formalin test and in an arthritic pain model in rats. Neuropharmacology 2009;56:564-571.

16. Nyfferler R, Bayer C, Alverson WS, Yen A et al. Phylogenetic analysis of the Malvandendrina clade (Malvaceae s. 1.) based on plastid DNA sequences. Org Divers Evol 2005;5:109-123.

17. Herrera-Ruiz M, Román-Ramos R, Zamilpa A, Tortoriello J et al. Flavonoids from Tilia americana with anxiolytic activity in plus-maze test. J Ethnopharmacol 2008;118:312-317.

18. Viola $H$, Wolfman $C$, Levi de Stein $M$, Wasowski $C$ et al. Isolation of pharmacologically active benzodiazepine receptor ligands from Tilia tomentosa (Tiliaceae). J Ethnopharmacol 1994;44:47-53.

19. Lister RG. The use of a plus-maze to measure anxiety in the mouse. Psychopharmacology 1987;92:180-185.

20. Clark G, Koster AG, Person DW. Exploratory behavior in chronic disulfotan poisoning in mice. Psychopharmacology (Berlin) 1997;20:169-171.

21. González-Trujano ME, Navarrete CA, Reyes B, Hong E. Some pharmacological effects of the ethanol extract of leaves of Annona diversifolia on the central nervous system in mice. Phytother Res 1998;2:600-602.
22. Coleta M, Campos MG, Cotrim MD, Cunha AP. Comparative evaluation of Melissa officinalis L., Tilia europea L., Passiflora edulis Sims. and Hypericum perforatum L. in the elevated plus maze anxiety test. Pharmacopsychiatry 2001;34(Suppl 1):S20-S21.

23. Pavón NP, Rico-Gray V. An endangered and potentially economic tree of Mexico: Tilia mexicana (Tiliaceae). Econ Bot 2000;54:113-114.

24. Gould KS, Lister C. Flavonoid functions in plant. In: Andersen OM, Markham KR (eds.). Flavonoids chemistry, biochemistry and applications, New York: CRC Tylor y Francis Group; 2006; p.397-441.

25. Dixon RA, Pavia NL. Stress-induced phenilpropanoid metabolism. Plant Cell 1995;7:1085-1097.

26. Salgueiro JB, Ardenghi P, Díaz M, Ferreira MBC et al. Anxiolytic natural and synthetic flavonoid ligands of the central benzodiazepine receptor have no effect on memory tasks in rats. Pharmacol Biochem Behav 1997;58:887-891.

27. Priprem A, Watanatorn J, Sutthiparinyanont S, Phachonpai W et al. Anxiety and cognitive effects of quercetin liposomes in rats. Nanomedicine 2008;4:70-78.

28. Rice-Evans CA, Miller NJ, Paganga G. Antioxidant properties of phenolic compounds. Trends Plant Sci 1997;2:152-159.

29. Shephard RA. Behavioral effects of GABA agonists in relation to anxiety and benzodiazepine action. Life Sci 1987;40:2429-2436.

30. Girish C, Raj V, Arya J, Balakrishnan S. Involvement of the GABAergic system in the anxiolytic-like effect of the flavonoid ellagic acid in mice. Eur J Pharmacol 2013;710:49-58.

31. De Carvalho RS, Duarte FS, De Lima TC. Involvement of GABAergic non-benzodiazepine sites in the anxiolytic-like and sedative effects of the flavonoid baicalein in mice. Behav Brain Res 2011;221:75-82.

32. Anderson W, Barrows M, Lopez F, Rogers $S$ et al. Investigation of the anxiolytic effects of naringenin, a component of Mentha aquatica, in the male Sprague-Dawley rat. Holist Nurs Pract 2012;26:52-57. 